\title{
PENGARUH STRUKTUR AKTIVA DAN OPERATING LEVERAGE TERHADAP STRUKTUR MODAL
}

\author{
Indira Shinta Dewi \\ dan \\ Kemia Indriyani \\ Fakultas Ekonomi Program Studi Akuntansi
Universitas Satya Negara Indonesia
}

ABSTRAK

Penelitian ini bertujuan untuk mengetahui pengaruh Struktur Aktiva dan Operating leverage terhadap Struktur Modal, serta variabel mana yang berpengaruh dominan terhadap struktur modal pada perusahaan makanan dan minuman yang terdaftar di Bursa Efek Indonesia.

Penelitian ini menggunakan pendekatan kuantitatif. Teknik pengumpulan data yang digunakan adalah data sekunder berupa laporan keuangan. Sumber data yang digunakan adalah data sekunder berupa laporan keuangan perusahaan makanan dan minuman yang terdaftar di BEI periode 2013-2016 yang dapat diperoleh melalui website www.idx.co.id. Teknik pengambilan sampel yang digunakan adalah purpose sampling dengan jumlah responden 16 perusahaan. Metode analisis data yang digunakan adalah analisis regresi linier berganda dengan menggunakan bantuan program SPSS 21 for Windows.

Hasil penelitian menyatakan bahwa (1) secara parsial Struktur Aktiva berpengaruh positif terhadap struktur modal, (2) Operating leverage tidak berpengaruh terhadap struktur modal, (3) secara simultan Struktur aktiva dan Operating Leverage berpengaruh signifikan terhadap Struktur modal pada perusahaan makanan dan minuman yang terdaftar di bursa efek indonesia.

Kata Kunci : Struktur Aktiva, Operating Leverage dan Struktur Modal

\begin{abstract}
This study aims to determine the effect of Asset Structure and Operating leverage on Capital structure, and which variables dominantly influence the capital structure in food and beverage companies listed on the Indonesian stock exchange.

This study uses a quantitative approach. Data collection techniques used in this research is the methode of documentation that is by collecting and recording the financial statements. Source data used are secondary data from the financial statements of food and beverage company listed on the Stock Exchange during the 2013-2016 period that can be obtained through the website www.idx.co.id. The sampling technique used was purposive sampling with the number of espondents 16 companies. Data analysis method used is multiple regression linear regression analysis using SPSS 21 for Windows.

The study states that (1) partially Asset structure significant postitive effect on capital structure, (2) Operating Leverage does not have effect on capital structure, (3) simultaneous Assets structure and Opearting leverage significant effect on capital structure in food and beverage companies listed on the Indonesian stock exchange.
\end{abstract}

Keywords : Assets structure, operating leverage, and capital structure 


\section{PENDAHULUAN}

Setiap perusahaan memiliki rencana yang disusun dalam rangka pencapaian tujuan yang telah ditetapkan. Salah satu aspek penting untuk mengimplementasikan rencana tersebut adalah rencana pembelanjaan. Kegagalan dalam rencana pembelanjaan akan menghambat aktivitas perusahaan, demikian pula sebaliknya. Pengaturan yang tepat dalam rencana pembelanjaan akan membantu perusahaan dalam menjalankan aktivitasnya.

Menghadapi persaingan tersebut setiap perusahaan memiliki rencana yang telah ditetapkan guna mencapai tujuan yang telah ditetapkan. Salah satu aspek penting untuk mengimplementasikan rencana tersebut adalah rencana pembelanjaan. Kegagalan dalam rencana pembelanjaan akan menghambat aktivitas perusahaan, demikian pula sebaliknya. Pengaturan yang tepat dalam rencana pembelanjaan akan membantu perusahaan dalam menjalankan aktivitasnya. Perimbangan dalam aktiva akan nampak pada struktur aktiva, sedangkan perimbangan dalam pasiva baik akan tercemin pada struktur modal. Struktur modal dapat menjadi masalah yang penting untuk perusahaan karena baik atau buruknya struktur modal akan berpengaruh langsung pada posisi finansial perusahaan.

Menurut Bambang (2012:22) struktur modal adalah pembelanjaan permanen dimana mencerminkan perimbangan antara hutang jangka panjang dengan modal sendiri.

Keseimbangan dalam menentukan pemenuhan kebutuhan belanja perusahaan dengan sumber pendanaan jangka panjang yang berasal dari dana internal dan dana eksternal, dengan demikian struktur modal adalah struktur keuangan dikurangi utang jangka pendek. Utang jangka pendek tidak diperhitungkan dalam struktur modal karena utang jangka pendek bersifat spontan (berubah sesuai dengan perubahan tingkat penjualan) sementara itu utang jangka panjang bersifat tetap selama jangka waktu yang relatif panjang (lebih dari satu tahun) sehingga keberadaannya perlu dipikirkan oleh para manajer keuangan.

Didalam struktur modal faktor-faktor yang mempengaruhi struktur modal adalah struktur aktiva dan operating leverage.

Menurut Bambang (2012:19) Struktur Aktiva adalah susunan dan penyajian aktiva dalam rasio tertentu dari laporan keuangan, yaitu perbandingan antara aktiva lancar dengan aktiva tetap.

Struktur aktiva digambarkan oleh aktiva tetap yang dijadikan jaminan untuk memenuhi kebutuhan perusahaan. Struktur aktiva menggambarkan proporsi antara aktiva total dengan aktiva tetap perusahaan, sebab perusahaan yang memiliki aktiva tetap yang besar akan lebih mudah mendapatkan modal dari luar perusahaan.

Struktur aktiva suatu perusahaan mempunyai dampak langsung pada struktur modal karena struktur aktiva suatu perusahaan merupakan jaminan ketika perusahaan meminjam uang ke kreditur untuk meningkatkan hutangnya, ketika kreditur tidak mempunyai informasi yang lengkap dan jelas mengenai perilaku perusahaan, maka perusahaan dengan sedikit struktur aktiva akan sulit untuk mendapatkan dana dari hutang, jika struktur aktiva besar perusahaan akan mudah dalam mendapatkan dana dari hutang.

Menurut (Sutrisno 2013:205), Operating Leverage adalah penggunaan aktiva yang menyebabkan perusahaan harus menanggung biaya tetap berupa penyusutan. Penggunaan operating leverage oleh perusahaan diharapkan agar penghasilan yang diperoleh atas penggunaan aktiva tetap tersebut cukup untuk menutup biaya tetap dan biaya variabel.

Jika sebagian besar dari total biaya perusahaan adalah biaya tetap, perusahaan ini dinyatakan memiliki operating leverage yang tinggi. Operating leverage merupakan salah satu yang mempengaruhi risiko bisnis, semakin besar DOL perusahaan semakin besar risiko bisnis perusahaan. Dengan kebijakan mempertahankan struktur modal maka perusahaan bisa 
meminimalisir akan penggunaan utang yang terkait dengan risiko yang akan dialami oleh perusahaan. Dapat dinyatakan bahwa semakin tinggi tingkat operating leverage (DOL), maka akan semakin rendah tingkat utang dan juga struktur modal perusahaan tersebut.

Operating leverage digunakan perusahaan dimana perubahaan penjualan akan mengakibatkan perusahaan laba sebelum pajak yang lebih besar, sesuai dengan pengukurannya yaitu dengan cara membandingkan antara persentase perubahaan EBIT dengan persentase perubahan penjualan.

Tingkat operating leverage yang tinggi memungkinkan perolehan keuntungan dari peningkatan volume penjualan, misalkan suatu perusahaan dapat meningkat volume penjualannya dengan cara menurunkan harga. Dengan penurunan harga tersebut, perusahaan dapat meningkatkan labanya. Karena operating leverage merupakan faktor penting untuk mempertimbangkan dalam pengambilan keputusan mengenai struktur modal perusahaan.

Dengan demikian, naik turunnya struktur modal dipengaruhi oleh naik turunnya struktur aktiva dan operating leverage, dimana menurunnya struktur aktiva dan operating leverage maka struktur modalnya akan menurun. Namun, berdasarkan pengamatan ditemukan bahwa struktur modal rendah tetapi memiliki struktur aktiva dan operating leverage menurun yang seperti terlihat pada emiten STTP (3).

\begin{tabular}{|c|c|c|c|c|}
\hline \multirow{2}{*}{ Eminten } & \multicolumn{2}{|c|}{2012} & \multicolumn{2}{c|}{2013} \\
\cline { 2 - 5 } & $\begin{array}{c}\text { Struktur } \\
\text { Aktiva (\%) }\end{array}$ & $\begin{array}{c}\text { Struktur } \\
\text { Modal (\%) }\end{array}$ & $\begin{array}{c}\text { Struktur } \\
\text { Aktiva (\%) }\end{array}$ & $\begin{array}{c}\text { Struktur } \\
\text { Modal (\%) }\end{array}$ \\
\hline INDF & 26,6 & 35,4 & 29,5 & 52,8 \\
\hline MYOR & 34,4 & 108 & 32,1 & 79,7 \\
\hline STTP & 52,1 & 17,1 & 51,5 & 25,9 \\
\hline TBLA & 33,7 & 112,4 & 53,5 & 119,3 \\
\hline
\end{tabular}

Dipilihnya perusahaan makanan dan minuman (foods dan beverages) karena industri tersebut cenderung intensif dalam modal guna pengembangan produk dan ekspansi pangsa pasarnya. Selain itu tingkat konsumsi masyarakat terhadap barang yang dihasilkan dalam industri tersebut sudah menjadi kebutuhan relatif tidak berubah baik kondisi perekonomian membaik maupun memburuk.

Penelitian Tommy Mardiansyah (2012) dengan hasil penelitian secara parsial dapat diketahui variabel Operating Leverage (DOL) berpengaruh negatif tidak signifikan terhadap struktur modal sedangkan dalam penelitian Selvia Nuraini dan Hardiwinoto (2014) menunjukkan hasil penelitiannya bahwa operating leverage berpengaruh positif dan signifikan terhadap struktur modal dengan metode pengujian melalui uji $\mathrm{F}$.

Penelitian Meidera Elsa Dwi Putri (2012) bahwa hasil penelitian secara parsial dapat diketahui variabel struktur aktiva berpengaruh positif dan signifikan terhadap struktur modal perusahaan, sedangkan dalam penelitian Selvia Nurani Sarasmita dan Hardiwinoto (2014) bahwa hasil penelitian dapat diketahui variabel struktur aktiva tidak berpengaruh terhadap struktur modal.

Berdasarkan latar belakang diatas maka penulis tertarik untuk mengadakan penelitian yang berjudul : "Pengaruh Struktur Aktiva dan Operating Leverage terhadap Struktur Modal Perusahaan Makanan dan Minuman yang Tedaftar di Bursa Efek Indonesia Periode 2013-2016". 


\section{Perumusan Masalah}

1. Apakah struktur aktiva berpengaruh terhadap struktur modal pada perusahaan makanan dan minuman periode 2013-2016?

2. Apakah operating leverage berpengaruh terhadap strukur modal pada perusahaan makanan dan minuman periode 2013-2016?

\section{Tujuan Penelitian}

Sesuai dengan perumusan masalah, maka tujuan dari penelitian ini adalah sebagai berikut :

1. Untuk mengetahui pengaruh struktur aktiva terhadap struktur modal pada perusahaan makanan dan minuman periode 2013-2016.

2. Untuk mengetahui pengaruh operating leverage terhadap struktur modal pada perusahaan makanan dan minuman periode 2013-2016.

\section{LANDASAN TEORI}

\section{Struktur Modal}

Struktur modal terdiri dari pendanaan jangka pendek, pendanaan jangka panjang, dan ekuitas. Hutang jangka pendek dan jangka panjang dapat diperoleh dari pihak eksternal perusahaan. Hutang jangka panjang akan digunakan oleh perusahaan untuk membiayai investasi modal. Hutang hipotek dan obligasi merupakan contoh hutang jangka panjang. Hutang hipotek dapat disebut juga secured debt. Agus dan Martono (2013:5)

Struktur modal pada dasarnya berkaitan dengan sumber dana, baik itu sumber internal maupun sumber eksternal. Sumber dana internal berasal dari dana yang terkumpul dari laba yang ditahan yang berasal dari kegiatan perusahaan, sedangkan sumber dana eksternal berasal dari pemilik yang merupakan komponen modal sendiri dan dana yang berasal dari para kreditur yang merupakan modal pinjaman atau hutang. Agus dan Martono (2013:17)

Struktur modal yang digunakan perusahaan merupakan kombinasi antara hutang dan ekuitas sehinga digambarkan dengan memperbandingkan antara hutang jangka panjang (long term debt) dengan jumlah modal sendiri (saham) yang digunakan perusahaan. Oleh sebab itu, struktur modal dapat diukur dengan rumus Bambang (2012:296) :

$$
\text { Struktur Modal }=\frac{\text { Utang Jangka Panjang }}{\text { Modal Sendiri }} \times 100 \%
$$

\footnotetext{
Aktiva

Menurut Djarwanto (2001:15) aktiva adalah bentuk dari penanaman modal perusahaan, bentuk-bentuknya dapat berupa harta kekayaan atau hak atas kekayaan atau jasa yang dimiliki perusahaan bersangkutan.

Menurut Mamduh (2009:24) aktiva adalah sumber daya yang dikuasai oleh peusahaan sebagai akibat dari peristiwa masa lalu dan darinya manfaat ekonomi dimasa depan diharapkan akan diraih oleh perusahaan.

Berdasarkan pengertian-pengertian diatas dapat disimpulkan bahwa aktiva adalah bentuk dari penanaman modal perusahaan, bentuk-bentuknya dapat berupa harta kekayaan, dan diharapkan mampu memberikan kontribusi baik secara langsung maupun tidak langsung dimasa yang akan datang.
}

\section{Struktur Aktiva}

Menurut Weston dan Brigham (2005:175) struktur aktiva adalah Perimbangan atau perbandingan antara aktiva tetap dan total aktiva. 
Menurut Syamsudin (2007:9) struktur aktiva adalah penentuan berapa besar alokasi dana untuk masing-masing komponen aktiva,baik dalam aktiva lancar maupun aktiva tetap.

Brigham dan Gapenski (1996) menyatakan bahwa secara umum perusahaan yang memiliki jaminan terhadap hutang akan lebih mudah mendapatkan hutang daripada perusahaan yang tidak memiliki jaminan.

Atmaja (2008) juga menyatakan bahwa perusahaan yang memiliki aktiva yang dapat digunakan sebagai jaminan hutang cenderung menggunakan hutang yang relatif besar.

Selvia dan Hardiwinoto (2014) menyatakan bahwa Struktur aktiva perusahaan yang memiliki aktiva tetap dalam jumlah besar dapat menggunakan hutang dalam jumlah besar, hal ini disebabkan karena dari skala perusahaan besar akan lebih mudah mendapatkan akses ke sumber dana dibandingkan dengan perusahaan kecil.

Bambang (2013:298) menyatakan bahwakebanyakan perusahaan industri dimana sebagian besar daripada modalnya tertanam dalam aktiva tetap, akan mengutamakan pemenuhan modalnya dari modal sendiri sedangkan hutang sifatnya sebagai pelengkap.

Yuniar (2015) mengemukakan bahwa struktur aktiva adalah kekayaan atau sumbersumber ekonomi yang dimiliki oleh perusahaan yang diharapkan akan memberikan manfaat dimasa yang akan datang, yang terdiri dari aktiva tetap, aktiva tidak berwujud, aktiva lancar dan aktiva tidak lancar.

Dari pengertian diatas dapat disimpulkan bahwa struktur aktiva merupakan perbandingan antara aktiva tetap dan total aktiva yang dapat menentukan besarnya alokasi dana untuk masing-masing komponen aktiva. Dengan kata lain, struktur aktiva dapat dihitung dengan rumus Bambang (2013:22) :

\section{Struktur Aktiva $=\underline{\text { Aktiva } \mathrm{T}}$}

Perusahaan yang memiliki aktiva tetap dalam jumlah besar dapat menggunakan hutang dalam jumlah besar, karena mereka memiliki jaminan yang besar pula. Apabila aktiva perusahaan cocok digunakan untuk dijadikan agunan kredit prusahaan tersebut cenderung menggunakan banyak hutang.

\section{Leverage}

Menurut Agus dan Martono (2013:315) Leverage adalah penggunaan aktiva dan sumber dana oleh perusahaan di mana dalam penggunaan aktiva atau dana tersebut perusahaan harus mengeluarkan biaya tetap atau beban tetap.

Masalah leverage timbul karena perusahaan menggunakan aktiva yang menyebabkan harus membayar biaya tetap dan menggunakan hutang yang menyebabkan perusahaan menanggung biaya tetap.

Menurut Sutrisno (2013:205) Leverage adalah penggunaan aktiva atau sumber dana di mana untuk penggunaan tersebut perusahaan harus menanggung biaya tetap atau membayar beban tetap.

Menurut Hery (2017:12) Leverage merupakan rasio yang menggambarkan kemampaun perusahaan dalam memenuhi seluruh kewajibanya, dalam menjalankan kegiatanya, tentu saja setiap perusahaan membutuhkan ketersediaan dana dalam jumlah yang memadai. Dana ini tidak hanya dibutuhkan untuk membiayai jalanya kegiatan operasional perusahaan saja, melainkan juga untuk mebiayai aktivitas investasi perusahaan, seperti mengganti atau membeli tambahan peralatan dan mesin produksi yang baru, dan sebagainya. 
Menurut Kasmir (2010:153) tujuan perusahaan dengan menggunakan leverage yakni :

1. Untuk mengetahui posisi perusahaan terhadap kewajiban kepada pihak lainnya (kreditor).

2. Untuk menilai kemampuan perusahaan dalam memenuhi kewajiban yang bersifat tetap (seperti angsuran pinjaman termasuk bunga).

3. Untuk menilai keseimbangan antara nilai aktiva khususnya aktiva tetap dengan modal.

4. Untuk menilai seberapa besar aktiva perusahaan dibiayai oleh utang.

5. Untuk menilai seberapa besar aktiva perusahaan dibiayai oleh utang.

6. Untuk menilai atau mengukur berapa bagian dari setiap rupiah modal sendiri yang dijadikan jaminan utang jangka panjang.

7. Untuk menilai berapa dana pinjaman yang segera akan ditagih, terdapat sekian kalinya modal sendiriyang dimiliki.

Dalam suatu perusahaan dikenal ada dua macam leverage, yaitu operating leverage dan financial leverage. Penggunaan kedua leverage ini dengan tujuan agar keuntungan yang diperoleh lebih besar daripada biaya aktiva dan sumber dananya. Dengan demikian, penggunaan leverage akan meningkatkan keuntungan bagi pemegang saham. Sebaliknya leverage juga dapat meningkatkan risiko keuntunga. Jika perusahaan mendapat keuntungan yang lebih rendah dari biaya tetapnya maka penggunaan leverage akan menurunkan keuntungan pemegang saham. Agus dan Martono (2013:315)

\section{Operating Leverage}

Menurut Brigham dan Houston (2011:160) Operating Leverage adalah sampai sejauh mana biaya tetap digunakan dalam operasi suatu perusahaan. Jika sebagian besar dari total biaya merupakan biaya tetap, maka perusahaan tersebut dikatakan memiliki tingkat operating leverage yang tinggi.

Menurut Agus dan Martono (2013:316) operating leverage timbul pada saat perusahaan menggunakan aktiva yang memiliki biaya-biaya operasi tetap. Biaya tetap tersebut misalnya biaya penyusutan gedung dan peralatan kantor, biaya asuransi dan biaya lain yang muncul dari penggunaan fasilitas dan biaya manajemen.

Operating Leverage mengukur perubahaan pendapatan atau penjualan terhadap keuntungan operasi. Dengan mengetahui operating leverage, maka manajemen bisa menaksir perubahan laba operasi dengan sebagai akibat perubahaan penjualan. Sutrisno (2013:206)

Operating Leverage dapat memperlihatkan pengaruh penjualan terhadap laba operasi atau laba sebelum bunga dan pajak (Earning Before Interest and Tax atau EBIT) yang diperoleh. Pengaruh tersebut dapat dicari dengan menghitung besarnya tingkat operating leverage yaitu Degree of Operating Leverage.

\section{Tingkat Operating Leverage (Degree of Operating Leverage)}

Tingkat operating leverage atau degree of operating leverage adalah persentase perubahan dalam laba operasi (EBIT) yang disebabkan perubahan satu persen dalam output (penjualan). Agus dan Martono (2013:317) Dengan demikian maka :

$$
\mathrm{DOL}=\frac{\% \text { perubahan } \mathrm{d}}{v}
$$

Menurut Agus dan Martono (2013:230) DOL merupakan salah satu komponen yang dapat menunjukkan risiko bisnis perusahaan. DOL perusahaan memperbesar dampak dari faktor lain pada variabilitas laba operasi. Meskipun DOL bukan sumber variabilitas. DOL 
yang tinggi tidak akan berpengaruh, bila perusahaan dapat memelihara penjualan dan struktur biaya yang konstan. Jadi DOL dapat dilihat sebagai suatu ukuran dari risiko potensial yang menjadi aktif hanya jika penjualan dan biaya produksi berubah-ubah.

Semakin besar penjualan berarti semakin besar laba operasi secara absolut berarti semakin jauh dari titik impas, sebaliknya DOL nya semakin kecil. Pada umumnya, perusahaan tidak senang beroperasi dengan DOL yang tinggi, karena penurunan sedikit dalam penjualan dapat mengakibatkan kerugian (penurunan laba yang besar sehingga menjadi rugi). Agus dan Martono (2013:321)

\section{Populasi dan Sample \\ Populasi}

\section{METODE PENELITIAN}

Populasi yang akan menjadi objek dalam penelitian ini adalah seluruh perusahaan makanan dan minuman yang terdaftar di Bursa Efek Indonesia (BEI) periode 2013-2016.

\section{Sampel}

Pengambilan sampel dengan menggunakan metode purposive sampling dengan kriteria sebagai berikut :

1. Perusahaan makanan dan minuman yang telah go public, terdaftar sebagai perusahaan makanan dan minuman (Food and Beverage) berturut-turut di Bursa Efek Indonesia (BEI) mulai tahun 2013 sampai dengan tahun 2016 (tidak pernah delisting).

2. Perusahaan menerbitkan laporan keuangan untuk periode berakhir 31 Desember selama rentang tahun penelitian yaitu 2013-2016.

\section{Metode Pengambilan Sampel}

Metode pengambilan sampel yang digunakan dalam penelitian ini adalah teknik purposive sampling, yaitu pengambilan sampel dari target spesifik yang akan mampu menyediakan informasi yang diinginkan karena mereka adalah satu-satunya yang bisa memberikan informasi yang dibutuhkan.

\section{Jenis dan Pengumpulan Data Jenis Data}

Data yang digunakan dalam penelitian ini adalah data sekunder. Pada penelitian ini, data yang digunakan adalah laporan keuangan perusahaan makanan yang terdaftar di Bursa Efek Indonesia (BEI) Periode 2013-2016, dimana datanya lebih terpercaya keabsahannya karena telah dipaksa oleh akuntan independen.

\section{Pengumpulan Data}

1. Metode Penelitian Lapangan (Field Research)

2. Metode Penelitian Kepustakaan (Library Research)

\section{Variabel Penelitian}

Variabel Dependen (Y)

Variabel dependen dalam penelitian ini adalah Struktur Modal.

\section{Variabrel Independen (X)}

Variabel independen yang digunakan dalam penelitian ini adalah Struktur Aktiva (X1) dan Operating Leverage (X2). 
$\underline{\text { Variabel Independen } \quad \underline{\text { Variabel Dependen }}}$

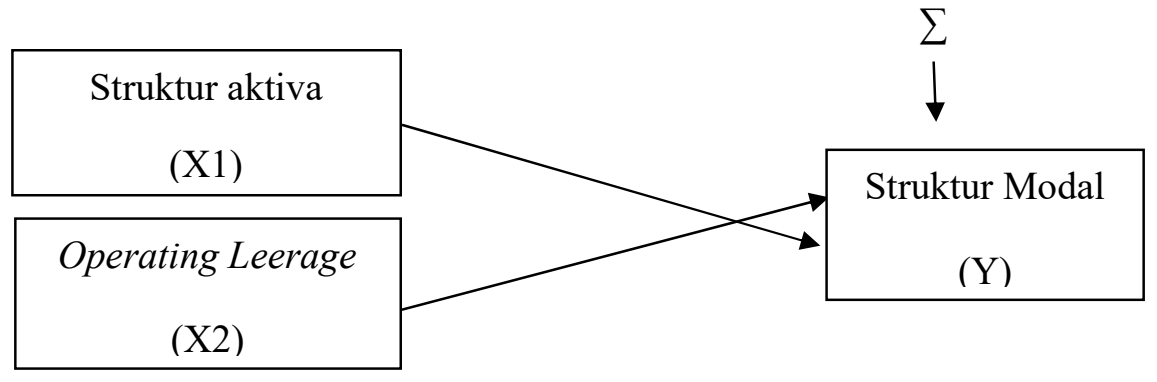

\author{
Gambar \\ Kerangka Pemikiran
}

\title{
Hipotesis
}

\section{Pengaruh Struktur Aktiva Terhadap Struktur Modal}

Struktur aktiva suatu perusahaan mempunyai dampak langsung pada struktur modal karena struktur aktiva suatu perusahaan merupakan jaminan ketika perusahaan meminjam uang ke kreditur untuk meningkatkan hutangnya, ketika kreditur tidak mempunyai informasi yang lengkap dan jelas mengenai perilaku perusahaan, maka perusahaan dengan sedikit struktur aktiva akan sulit untuk mendapatkan dana dari hutang, jika struktur aktiva besar perusahaan akan mudah dalam mendapatkan dana dari hutang.

$\mathrm{H}_{1}$ : Struktur Aktiva berpengaruh positif terhadap struktur modal perusahaan makanan dan minuman yang terdaftar di Bursa Efek Indonesia

\section{Pengaruh Operating Leverage Terhadap Struktur Modal}

Jika sebagian besar dari total biaya perusahaan adalah biaya tetap, perusahaan ini dinyatakan memiliki operating leverage yang tinggi. Operating leverage merupakan salah satu yang mempengaruhi risiko bisnis, semakin besar DOL perusahaan semakin besar risiko bisnis perusahaan. Dengan kebijakan mempertahankan struktur modal maka perusahaan bisa meminimalisir akan penggunaan utang yang terkait dengan risiko yang akan dialami oleh perusahaan. Dapat dinyatakan bahwa semakin tinggi tingkat operating leverage (DOL), maka akan semakin rendah tingkat utang dan juga struktur modal perusahaan tersebut.

$\mathrm{H}_{2}$ : Operating leverage berpengaruh negatif terhadap struktur modal perusahaan makanan dan minuman yang terdaftar di Bursa Efek Indonesia.

\section{Metode Analisis Data}

\section{Analisis Deskriptif}

Prof.Dr.Sugiyono (2016:147) mengatakan statistic deskriptif adalah statistik yang digunakan untuk menganalisis data dengan cara mendeskripsikan atau menggambarkan data yang telah terkumpul sebagaimana adanya tanpa bermaksud membuat kesimpulan yang berlaku umum atau generalisasi, seperti gambaran terhadap objek yang diteliti melalui data sampel atau populasi. 


\section{Analisis Statistik \\ Uji Asumsi Klasik}

\section{Uji Normalitas}

Bertujuan menguji apakah dalam model regresi, variabel terikat dan variabel bebas keduanya mempunyai distribusi normal ataukah tidak. Adapun cara analisis yang dilakukan adalah :

1. Menggunakan grafik normal plot yaitu jika penyebaran data mengikuti garis normal, maka data berdistribusi normal.

2. Melihat kolmogrov swimov dengan nilai signifikan diatas 0,05 maka data terdistribusi normal. Ghozali (2016:154)

\section{Uji Multikolinearitas}

Bertujuan untuk menguji model regresi ditemukan adanya korelasi antara variabel bebas (independent). Langkah menganalisis asumsi multikoloneritas yaitu :

1. Jika nilai VIF lebih kecil dari angka 10 maka tidak terjadi problem multikolonieritas.

2. Jika nilai tolerance lebih besar dari 0,10 maka tidak terjadi problem multikolonieritas Ghozali (2016:103).

\section{Uji Heteroskedastisitas}

Cara untuk mendeteksi ada atau tidaknya heteroskedastisitas yaitu :

1. Uji Glejser

Jika variabel independen signifikan secara statistik mempengaruhi variabel dependen, maka tidak ada indikasi terjadi Heteroskedastisitas. Imam Ghozali (2016:139)

2. Melihat grafik plot

\section{Uji Autokorelasi}

Model regresi yang baik adalah regresi yang bebas dari autokorelasi. Metode pengujian yang sering digunakan adalah dengan uji Durbin-Watson (Uji DW) dengan ketentuan sebagai berikut Ghozali (2016:107-108)

\section{Koefisien Determinasi (Uji R $\left.\mathbf{R}^{2}\right)$}

Pada koefisien determinasi $\left(\mathrm{R}^{2}\right)$ pada intinya mengukur seberapa jauh kemampuan model dalam menerangkan variasi variabel dependen. Nilai koefisien determinasi adalah antara nol dan satu. Nilai $\mathrm{R}^{2}$ yang kecil berarti kemampuan variabel-variabel independen memberikan hamper semua informasi yang dibutuhkan untuk memprediksi variasi variabel dependen. Ghozali (2016:329)

\section{Uji Regresi Linear Berganda Uji Statistik F (Uji Simultan)}

Uji Statistik $\mathrm{F}$ adalah metode pengujian yang dilakukan untuk mengetahui pengaruh variable bebas secara bersama-sama terhadap variabel terikat. Dengan tongkat kepercayaan untuk pengujian hipotesis adalah $95 \%$ atau $(\alpha)=0,05$. Jika Fhitung $>$ Ftabel, Artinya semua variabel bebas secara bersama-sama merupakan penjelas yang signifikan terhadap variabel terikat. Namun, jika Fhitung < dari Ftabel, artinya semua variabel bebas secara bersama-sama bukan merupakan variabel penjelas yang signifikan terhadap variabel terikat. 


\section{Uji t}

Menurut Ghozali (2016:99) Nilai signifikan $<0,05$ maka variabel independen berpengaruh terhadap variabel dependen (Ho ditolak dan Ha diterima), sehingga nilai signifikan $>0,05$ maka variabel independen tidak berpengaruh terhadap variabel dependen .

\section{Persamaan Linear Berganda}

Persamaan regresi linear berganda dengan menggunakan dua variabel dapat dinyatakan dalam persamaan. Secara umum model regresi ini dapat ditulis sebagai berikut:

$$
Y=a+\beta_{1} X_{1}+\beta_{2} X_{2}+e
$$

Keterangan:

Y

$\mathrm{X}_{1}$

$\mathrm{X}_{2}$

$\beta_{1} \beta_{2}$

a

e
$=$ Struktur Modal

$=$ Struktur Aktiva

= Operating Leverage

$=$ Koefisien regresi

= Konstanta

$=$ Error term

\section{ANALISIS HASIL DAN PEMBAHASAN}

\section{Deskripsi Objek Penelitian}

\section{Populasi dan Sampel}

Selama tahun 2013-2016 terdapat 64 perusahaan makanan dan minuman yang terdaftar di Bursa Efek Indonesia. Proses purposive purposive sampling penelitian pada tabel berikut :

\section{Proses Seleksi Sampel Berdasarkan Kriteria}

\begin{tabular}{|c|l|c|c|c|c|}
\hline No. & \multicolumn{1}{|c|}{ Kriteria } & $\begin{array}{c}\text { Tahun } \\
\mathbf{2 0 1 3}\end{array}$ & $\begin{array}{c}\text { Tahun } \\
\mathbf{2 0 1 4}\end{array}$ & $\begin{array}{c}\text { Tahun } \\
\mathbf{2 0 1 5}\end{array}$ & $\begin{array}{c}\text { Tahun } \\
\mathbf{2 0 1 6}\end{array}$ \\
\hline 1 & $\begin{array}{l}\text { Perusahaan makanan dan minuman } \\
\text { yang terdaftar di Bursa Efek } \\
\begin{array}{l}\text { Indonesia selama periode 2013- } \\
2015\end{array}\end{array}$ & $\mathbf{1 6}$ & $\mathbf{1 6}$ & $\mathbf{1 6}$ & $\mathbf{1 6}$ \\
\hline 2 & $\begin{array}{l}\text { Perusahaan yang tidak menerbitkan } \\
\text { laporan keuangan }\end{array}$ & $\mathbf{( 3 )}$ & $\mathbf{( 3 )}$ & $\mathbf{( 2 )}$ & $\mathbf{( 3 )}$ \\
\hline 3 & Sampel yang diteliti & $\mathbf{1 3}$ & $\mathbf{1 3}$ & $\mathbf{1 4}$ & $\mathbf{1 3}$ \\
\hline 4 & Jumlah sampel & \multicolumn{3}{|c|}{$\mathbf{5 3}$} & \\
\hline
\end{tabular}

Dengan demikian setelah dilakukan metode purpose sampling maka didapatkan jumlah sampel penelitian sebanyak 53 observasi. 


\section{Analisa Deskriptif}

Analisis deskriptif dilakukan untuk memberikan gambaran dan deskripsi dari data penelitian. Analisis deskriptif dapat dilihat dalam table berikut.

Descriptive Statistics

\begin{tabular}{|l|r|r|r|r|r|r|}
\hline & \multicolumn{1}{|c|}{$\mathrm{N}$} & $\begin{array}{c}\text { Minimu } \\
\mathrm{m}\end{array}$ & $\begin{array}{c}\text { Maximu } \\
\mathrm{m}\end{array}$ & \multicolumn{2}{|c|}{ Mean } & \multicolumn{1}{c|}{$\begin{array}{c}\text { Std. } \\
\text { Deviation }\end{array}$} \\
\cline { 2 - 7 } & Statistic & Statistic & Statistic & Statistic & $\begin{array}{c}\text { Std. } \\
\text { Error }\end{array}$ & \multicolumn{1}{c|}{ Statistic } \\
\hline Struktur Aktiva & 53 & 2,08 & 4,54 & 3,5252 &, 07435 &, 54127 \\
Operating & 42 & $-3,91$ & 6,86 & 1,0608 &, 25974 & 1,68331 \\
Leverage & & & & & & 1,02036 \\
Struktur Modal & 53 & 1,34 & 4,55 & 3,1870 &, 14016 & 1,03 \\
Valid N (listwise) & 42 & & & & & \\
\hline
\end{tabular}

\section{Analisa Statistik}

\section{Uji Asumsi Klasik}

\section{Uji Normalitas Data}

Grafik normal P-P of Regression standardized Residual menunjukkan bahwa titik-titik menyebar disekitar garis diagonal serta menunjukkan pola distribusi normal pada grafik P-P of Regression standardized Residual penelitian ini dapat dilihat pada gambar berikut:

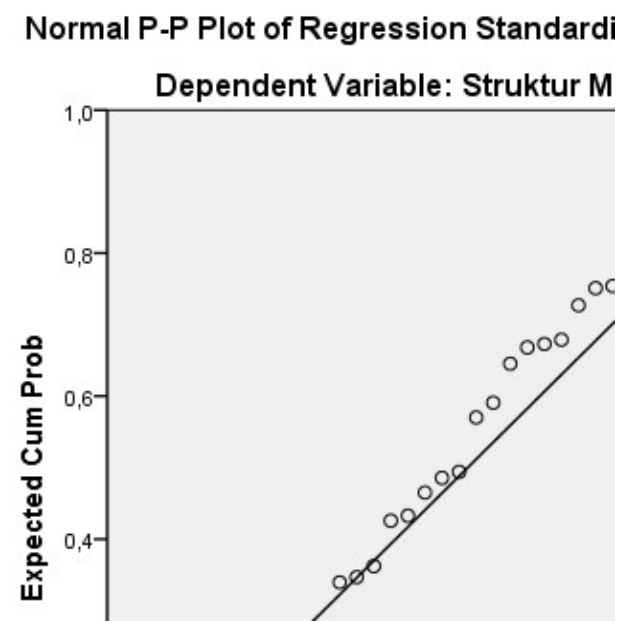

\section{Uji Normalitas}

Selain berdasarkan grafik normal P-P of Regression Standardized Residual dan grafik normal histogram pendeteksian normalitas data dapat dilakukan dengan melihat Kolmogorov Swirnov untuk mengetahui apakah data terdistribusi secara normal atau tidak. Hasil uji Kolmogorov Swirnov dapat dilihat pada tabel berikut: 
Hasil Uji Kolmogrov Swirnov

One-Sample Kolmogorov-Smirnov Test

\begin{tabular}{|ll|r|r|r|}
\hline & \multicolumn{1}{|c|}{$\begin{array}{c}\text { Struktur } \\
\text { Aktiva }\end{array}$} & \multicolumn{1}{c|}{$\begin{array}{c}\text { Operating } \\
\text { Leverage }\end{array}$} & \multicolumn{1}{c|}{$\begin{array}{c}\text { Struktur } \\
\text { Modal }\end{array}$} \\
\hline $\mathrm{N}$ & Mean & 53 & 42 & 53 \\
Normal Parameters & a,b & 3,5252 & 1,0608 & 3,1870 \\
& Std. &, 54127 & 1,68331 & 1,02036 \\
Most Extreme & Deviation & & & \\
Differences & Absolute &, 087 &, 140 &, 140 \\
Kolmogorov-Smirnov Z & Positive &, 065 &, 140 &, 106 \\
Asymp. Sig. (2-tailed) &,- 087 &,- 127 &,- 140 \\
\hline
\end{tabular}

a. Test distribution is Normal.

b. Calculated from data.

Berdasarkan hasil uji normalitas dengan Kolmogrov Smirnov diatas terlihat bahwa nilai signifikan untuk Struktur Aktiva sebesar 0,822. Nilai signifikan untuk Operating Leverage sebesar 0,381. Nilai signifikan untuk Struktur Modal sebesar 0,251 lebih besar dari 0,05 sehingga dapat disimpulkan bahwa data berdistribusi secara normal.

\section{Uji Multikolinearitas}

Uji multikolinearitas dapat juga dilihat dari (1) nilai tolerance dan lawanya (2) VIF (variance inflation factors) (Ghozali, 2016: 103). Batas dari tolerance value adalah 0,10 dan batas VIT adalah 10 apabila tolerance value $>0,10$ dan nilai VIT $<10$ maka tidak terjadi multikolinieritas. Hasil uji multikolinieritas dapat dilihat pada tabel berikut:

\section{Hasil Uji Multikolinieritas}

Coefficients $^{\text {a }}$

\begin{tabular}{|c|c|c|c|c|c|c|c|}
\hline \multirow[t]{2}{*}{ Model } & \multicolumn{2}{|c|}{$\begin{array}{l}\text { Unstandardized } \\
\text { Coefficients }\end{array}$} & \multirow{2}{*}{\begin{tabular}{|c}
$\begin{array}{c}\text { Standard } \\
\text { ized } \\
\text { Coefficie } \\
\text { nts }\end{array}$ \\
Beta
\end{tabular}} & \multirow[t]{2}{*}{$\mathrm{T}$} & \multirow[t]{2}{*}{ Sig. } & \multicolumn{2}{|c|}{$\begin{array}{l}\text { Collinearity } \\
\text { Statistics }\end{array}$} \\
\hline & B & $\begin{array}{l}\text { Std. } \\
\text { Error }\end{array}$ & & & & $\begin{array}{c}\text { Tolera } \\
\text { nce }\end{array}$ & VIF \\
\hline (Constant) &,- 056 &, 875 & &,- 064 & ,949 & & \\
\hline $\begin{array}{l}\text { Struktur } \\
\text { Aktiva }\end{array}$ & ,910 & ,244 &, 511 & 3,724 & ,001 & ,998 & \\
\hline $\begin{array}{l}\text { Operating } \\
\text { Leverage }\end{array}$ & ,039 & ,082 & ,066 &, 478 & ,635 & ,998 & 1,002 \\
\hline
\end{tabular}

a. Dependent Variable: Struktur Modal

Berdasarkan tabel hasil ouput SPSS diatas menunjukkan besarnya nilai Tolerance dan Variabel Inflation Factor (VIF) untuk masing-masing variabel independen yaitu tolerance > 0,10 dan VIF $<10$ sehingga dapat disimpulkan bahwa antar variabel variabel independen tidak terjadi multikolinieritas. 
Penjelasan adalah sebagai berikut:

1. Variabel Struktur Aktiva tolerance $0,998>0,10$ dan VIF $1,002<10$ sehingga tidak terjadi multikolinieritas.

2. Variabel Operating Leverage tolerance 0,998 $>0,10$ dan VIF 1,002 $<10$ sehingga tidak terjadi multikolinieritas.

\section{Uji Heteroskedastisitas}

Uji Heteroskedastisitas

Coefficients ${ }^{\mathrm{a}}$

\begin{tabular}{|c|c|c|c|c|c|c|}
\hline \multirow{2}{*}{\multicolumn{2}{|c|}{ Model }} & \multicolumn{2}{|c|}{$\begin{array}{l}\text { Unstandardized } \\
\text { Coefficients }\end{array}$} & \multirow{2}{*}{$\begin{array}{c}\begin{array}{c}\text { Standardize } \\
\mathrm{d} \\
\text { Coefficients }\end{array} \\
\text { Beta }\end{array}$} & \multirow[t]{2}{*}{$\mathrm{t}$} & \multirow[t]{2}{*}{ Sig. } \\
\hline & & B & Std. Error & & & \\
\hline \multirow{3}{*}{1} & (Constant) & ,579 & ,443 & & 1,307 & , 199 \\
\hline & Struktur Aktiva &, 048 & ,124 &, 062 & ,389 & 699 \\
\hline & $\begin{array}{l}\text { Operating } \\
\text { Leverage }\end{array}$ &,- 012 &, 042 &,- 045 &,- 281 & ,780 \\
\hline
\end{tabular}

a. Dependent Variable: abs

Dari tabel coefficients diatas dengan menggunakan uji glejser menunjukkan bahwa model penelitian tidak mengalami gangguan heterokedastisitas. Karena tingkat nilai signifikan diatas 0,05 .

\section{Uji Autokorelasi}

Model regresi yang baik adalah regresi yang bebas dari autokorelasi. Metode pengujian yang sering digunakan adalah dengan uji Durbin-Watson (Uji DW). Berdasarkan output SPSS berikut adalah nilai Durbin-Watson pada penelitian ini dapat dilihat tabel berikut:

\section{Uji Autokolerasi \\ Model Summary}

\begin{tabular}{|c|c|c|c|c|c|c|c|c|c|c|}
\hline \multirow{2}{*}{$\begin{array}{l}\text { M } \\
\text { od } \\
\text { el }\end{array}$} & \multirow[t]{2}{*}{$\mathrm{R}$} & \multirow{2}{*}{$\begin{array}{c}\mathrm{R} \\
\text { Squ } \\
\text { are }\end{array}$} & \multirow{2}{*}{$\begin{array}{l}\text { Adjust } \\
\text { ed R } \\
\text { Square }\end{array}$} & \multirow[b]{2}{*}{$\begin{array}{l}\text { Std. } \\
\text { Error } \\
\text { of the } \\
\text { Estima } \\
\text { te }\end{array}$} & \multicolumn{5}{|c|}{ Change Statistics } & \multirow{2}{*}{$\begin{array}{c}\text { Durbin } \\
- \\
\text { Watso } \\
n\end{array}$} \\
\hline & & & & & $\begin{array}{c}\mathrm{R} \\
\text { Square } \\
\text { Chang } \\
\mathrm{e}\end{array}$ & $\begin{array}{c}\text { F } \\
\text { Cha } \\
\text { nge }\end{array}$ & df1 & df2 & $\begin{array}{c}\text { Sig. F } \\
\text { Chang } \\
\text { e }\end{array}$ & \\
\hline 1 & $\begin{array}{r}, 51 \\
8^{\mathrm{a}}\end{array}$ & 268, & ,230 & ,88670 & ,268 & $\begin{array}{r}7,14 \\
1\end{array}$ & 2 & 39 & ,002 & 2,292 \\
\hline
\end{tabular}

a. Predictors: (Constant), Operating Leverage, Struktur Aktiva

b. Dependent Variable: Struktur Modal

Dari hasil uji pada tabel diatas uji Autokorelasi dengan uji Durbin-Watson menunjukkan nilai 1,6061 uji autokorelasi dapat diuji dengan rumus DU $<$ D $<4-$ DU diketahui bahwa berdasarkan tabel Durbin Watson dengan sampel penelitian 42 dan presentasi 5\%, maka DU yang dimiliki adalah 1,6061. Jadi dapat disimpulkan 1,6061 $<2,292<2,3939$ maka diindikasi bahwa tidak terdapat Autokorelasi dalam penelitian ini. 


\section{Koefisien Determinasi}

\begin{tabular}{l|r|r|r|r|}
\multicolumn{9}{c|}{$\begin{array}{l}\text { Koefisien Determinasi } \\
\text { Model Summary }\end{array}$} \\
\begin{tabular}{|l|r|r|r|r|}
\hline $\begin{array}{l}\text { Mode } \\
1\end{array}$ & R & R Square & $\begin{array}{l}\text { Adjusted R } \\
\text { Square }\end{array}$ & $\begin{array}{l}\text { Std. Error of } \\
\text { the Estimate }\end{array}$ \\
\hline 1 &, $518^{\mathrm{a}}$ &, 268 &, 230 &, 88670 \\
\hline
\end{tabular}
\end{tabular}

a. Predictors: (Constant), Operating Leverage, Struktur

Aktiva

b. Dependent Variable: Struktur Modal

Berdasarkan tabel diatas diperoleh bahwa nilai koefisien determinasi (adjusted $\mathrm{R}^{2}$ ) sebesar 0,230 atau sebesar 23\%. Hal ini berarti bahwa variabel Struktur Aktiva dan Operating Leverage mampu menjelaskan variabel Struktur Modal sebesar 23\%, sedangkan sisanya $77 \%$, dipengaruhi oleh faktor-faktor lain yang tidak dimasukkan dalam penelitian ini.

Uji Regresi Berganda Menguji Statistik F (Uji Simultan)

Uji Anova

ANOVA ${ }^{\mathrm{a}}$

\begin{tabular}{|c|c|c|c|c|c|c|}
\hline \multicolumn{2}{|c|}{ Model } & $\begin{array}{l}\text { Sum of } \\
\text { Squares }\end{array}$ & Df & $\begin{array}{l}\text { Mean } \\
\text { Square }\end{array}$ & F & Sig. \\
\hline \multirow{3}{*}{1} & Regression & 11,228 & 2 & 5,614 & 7,141 &, $002^{b}$ \\
\hline & Residual & 30,663 & 39 & ,786 & & \\
\hline & Total & 41,892 & 41 & & & \\
\hline
\end{tabular}

a. Dependent Variable: Struktur Modal

b. Predictors: (Constant), Operating Leverage, Struktur Aktiva

Berdasarkan tabel di atas menunjukkan bahwa $F_{\text {hitung }}$ sebesar 7,141 dimana $F_{\text {hitung }}$ bernilai lebih besar dari $\mathrm{F}_{\text {tabel }}$ sebesar 3,33 $(7,141>3,33)$ dan tingkat signifikan $\mathrm{F}_{\text {hitung }}$ sebesar 0,002 yang memiliki nilai lebih kecil dari tingkat signifikan $F_{\text {tabel }}$ sebesar $0,05(0,002<$ 0,05). Dengan demikian berarti Ho ditolak dan Ha diterima sehingga dapat disimpulkan bahwa Struktur Aktiva dan Operating Leverage berpengaruh secara bersama-sama (simultan) terhadap Struktur Modal.

Uji t

Menentukan nilai $t_{\text {tabel }}$ dapat ditentukan dengan tingkat signifikansi 5\% dengan derajat kebebasan $\mathrm{df}=(\mathrm{n}-\mathrm{k}-1)$ dimana $\mathrm{n}$ adalah jumlah sampel dan $\mathrm{k}$ adalah jumlah variabel. $\mathrm{T}$ tabel dapat dilihat pada tabel statistik pada signifikansi 0,05 dengan derajat kebebasan $(\mathrm{df})=\mathrm{n}-\mathrm{k}-1$ $=42-2-1=29$. Hasil yang diperoleh untuk tabel sebesar 2,023 kriteria pengujian yang digunakan adalah :

1. Jika sig $<0,05$, Maka Ho ditolak dan Ha diterima

2. Jika sig $>0,05$, Maka Ho diterima dan Ha ditolak 
Sedangkan $t_{\text {hitung }}$ dapat dilihat dari hasil output SPSS pada tabel diatas coefficient sebagai berikut :

\section{Uji Parsial (Uji t)}

Coefficients $^{\mathrm{a}}$

\begin{tabular}{|c|c|c|c|c|c|}
\hline \multirow[t]{2}{*}{ Model } & \multicolumn{2}{|c|}{$\begin{array}{l}\text { Unstandardized } \\
\text { Coefficients }\end{array}$} & \multirow{2}{*}{$\begin{array}{c}\begin{array}{c}\text { Standardize } \\
\mathrm{d} \\
\text { Coefficient } \\
\mathrm{s}\end{array} \\
\text { Beta }\end{array}$} & \multirow[t]{2}{*}{$\mathrm{t}$} & \multirow[t]{2}{*}{ Sig. } \\
\hline & B & Std. Error & & & \\
\hline (Constant) &,- 056 &, 875 & &,- 064 & ,949 \\
\hline Struktur Aktiva & ,910 & ,244 & ,511 & 3,724 & ,001 \\
\hline $\begin{array}{l}\text { Operating } \\
\text { Leverage }\end{array}$ & ,039 & ,082 & ,066 &, 478 & ,635 \\
\hline
\end{tabular}

a. Dependent Variable: Struktur Modal

Berdasarkan tabel diatas, maka dapat dijelaskan mengenai pengaruh secara parsial masing-masing variabel independen sebagai berikut :

\section{Pengaruh Struktur Aktiva Terhadap Struktur Modal}

Dari tabel diatas menunjukkan bahwa tingkat signifikan sebesar 0,001 yang memiliki nilai lebih kecil dari tingkat signifikan $0,05(0,001<0,05)$. Dengan keadaan tersebut maka Ho ditolak dan Ha diterima. Hal ini berarti bahwa Struktur Aktiva berpengaruh positif terhadap Struktur Modal.

\section{Pengaruh Operating Lverage Terhadap Struktur Modal}

Dari tabel diatas menunjukkan bahwa memiliki nilai lebih besar dari tingkat signifikan $0,05(0,635>0,05)$. Dengan keadaan tersebut maka Ho diterima dan Ha ditolak. Hal ini berarti bahwa Operating Leverage tidak berpengaruh terhadap Struktur Modal.

\section{Persamaan Regresi Linear Berganda}

Hasil uji koefisen regresi dapat dilihat pada tabel tersebut menunjukkan hasil pengujian dengan regresi pada tingkat signifikan 0,05

\section{Uji Koefisien Regresi}

\section{Coefficients $^{\mathrm{a}}$}

\begin{tabular}{|c|c|c|c|c|c|c|}
\hline \multirow{2}{*}{\multicolumn{2}{|c|}{ Model }} & \multicolumn{2}{|c|}{$\begin{array}{l}\text { Unstandardized } \\
\text { Coefficients }\end{array}$} & \multirow{2}{*}{$\begin{array}{c}\text { Standardized } \\
\text { Coefficients }\end{array}$} & \multirow[t]{2}{*}{$\mathrm{t}$} & \multirow[t]{2}{*}{ Sig. } \\
\hline & & B & Std. Error & & & \\
\hline \multirow{3}{*}{1} & (Constant) &,- 056 &, 875 & &,- 064 & ,949 \\
\hline & Struktur Aktiva & ,910 & 244 & ,511 & 3,724 & ,001 \\
\hline & $\begin{array}{l}\text { Operating } \\
\text { Leverage }\end{array}$ & ,039 & ,082 & ,066 & ,478 & ,635 \\
\hline
\end{tabular}

a. Dependent Variable: Struktur Modal 
Berdasarkan tabel diatas maka dapat disusun persamaan regresi berganda sebagai berikut

$\mathrm{Y}($ Struktur Modal $)=\mathbf{- 0 , 0 5 6}+\mathbf{0 , 9 1 0}($ Struktur aktiva) $+\mathbf{0 , 0 3 9}$ Operating Leverage $)+\mathrm{e}$

Dari persamaan regresi di atas dapat diinterprestasikan beberapa hal antara lain:

1. Nilai Constant sebesar -0,056 menyatakan bahwa jika variabel independen dianggap konstan, maka struktur modal akan mengalami penurunan sebesar $-0,056$.

2. Nilai koefisien regresi Struktur Aktiva sebesar 0,910 artinya adalah jika variabel lain nilainya tetap dan Struktur Aktiva mengalami kenaikan sebesar 1\%, maka Nilai Perusahaan akan mengalami kenaikan sebesar 0,910\%.

3. Nilai koefisien regresi Operating Leverage sebesar 0,039 artinya adalah jika variabel independen lain nilainya tetap dan Operating Leverage mengalami kenaikan sebesar 1\%, maka Nilai Perusahaan akan mengalami penurunan sebesar 0,039\%.

\section{Pembahasan dan Interprestasi \\ Hasil Penelitian Dengan Landasan Teori}

\section{Pengaruh Struktur Aktiva Terhadap Struktur Modal}

Berdasarkan hasil uji statistik menunjukkan bahwa secara parsial struktur aktiva berpengaruh terhadap struktur modal.

Struktur aktiva merupakan jaminan perusahaan dalam memperoleh dana dari kreditur, ketika kreditur tidak mempunyai informasi lengkap dan jelas mengenai perilaku perusahaan, maka kreditur akan melihat dari struktur aktiva perusahaan tersebut. Semakin besar struktur aktiva akan mempermudah perusahaan untuk memperoleh sumber dana, yang kemudian dapat dimanfaatkan oleh pihak manajemen untuk tujuan meningkatkan struktur modal.

Semakin tinggi struktur aktiva menunjukkan bahwa hutang yang diambil oleh perusahaan juga semakin besar. Dengan mengasumsikan hal lain konstan, maka jika aktiva tetap perusahaan meningkat, penggunaan hutang juga akan meningkat. Selain itu semakin tinggi jaminan yang akan diberikan perusahaan kepada kreditur, akan semakin besar pula jumlah hutang yang dapat diberikan oleh kreditur kepada perusahaan. Kreditur sangat berhati-hati dalam memberikan hutang kepada perusahaan, dan pihak kreditur mungkin hanya akan memberikan hutang baru kepada perusahaan ketika kreditur tersebut mendapatkan jaminan yang memberikan kepastian perlindungan bagi kepentingan mereka. Jaminan yang dapat memberikan kepastian perlindungan bagi pihak kreditur adalah aktiva tetap yang dimiliki perusahaan.

Hasil penelitian ini sejalan dengan hasil penelitian yang dilakukan Selvia Nuraini dan Hardiwinoto (2014) yang meneliti mengenai pengaruh struktur aktiva, profitabilitas, operating leverage dan tingkat pertumbuhan terhadap struktur modal yang memberi kesimpulan struktur aktiva berpengaruh positif terhadap struktur modal.

\section{Pengaruh Operating Leverage Terhadap Struktur Modal}

Berdasarkan hasil analisis statistik menunjukkan bahwa secara parsial operating leverage tidak berpengaruh terhadap struktur modal.

Operating leverage merupakan pengukuran sejauh mana biaya tetap yang telah digunakan dalam operasi suatu perusahaan. Jika sebagian besar dari total biaya merupakan biaya tetap, maka perusahaan tersebut dikatakan memiliki tingkat operating leverage yang tinggi. 
Semakin tinggi operating leverage perusahaan mengakibatkan meningkatnya risiko bisnis perusahaan. Pada saat risiko tinggi, perusahaan lebih mempertahankan struktur modalnya atau mengurangi penggunaan dana eksternal yang lebih besar.

Hasil ini tidak sejalan dengan penelitian Mega Junita, Azwir Nasir dan Elfi Ilham (2014) yang meneliti pengaruh profitabilitas, pertumbuhan aset, operating leverage dan ukuran perusahaan terhadap struktur modal pada perusahaan food and beverage yang memberi kesimpulan operating leverage berpengaruh terhadap struktur modal.

\section{KESIMPULAN DAN SARAN}

\section{Kesimpulan}

Berdasarkan hasil analisis data mengenai pengaruh Struktur Aktiva dan Operating Leverage perusahaan makanan dan minuman yang terdaftar di Bursa Efek Indonesia periode tahun 2013-2016, dapat disimpulkan bahwa :

1. Struktur Aktiva berpengaruh terhadap Struktur Modal.

2. Operating Leverage tidak berpengaruh terhadap Struktur Modal.

\section{Saran}

Berdasarkan kesimpulan yang sudah dipaparkan di atas, maka dapat disampaikan beberapa saran sebagai berikut:

1. Perusahaan yang digunakan dalam analisis data bisa menggunakan sektor lain selain sektor konsumsi atau menguji keseluruhan jenis perusahaan.

2. Penelitian selanjutnya diharapkan menambah atau mengubah variabel lain seperti stabilitas penjualan, tingkat pertumbuhan, profitabilitas, pajak, pengendalian sikap manajemen yang merupakan faktor-faktor mempengaruhi setruktur modal, karena untuk struktur aktiva dan operating leverage hanya berpengaruh 3,33\% terhadap struktur modal. 


\section{DAFTAR PUSTAKA}

Agus dan Martono. 2013. Manajemen Keuangan. Edisi 2. Yogyakarta: EKONISIA.

Atmaja, Lukas Setia. 2003. Manajemen Keuangan. Yogyakarta: Andi Offset.

Djarwanto. 2004. Pokok-Pokok Analisis Laporan Keuangan, Edisi 2. Yogyakarta: BPFE Yogyakarta.

Fith Yuniar Ichwan. 2015. Pengaruh Ukuran Perusahaan, Struktur Aktiva dan Profitabilitas Terhadap Struktur Modal. Jurnal STIESIA Surabaya.

Ghozali, Imam. 2016. Aplikasi AnalisisMultivariete dengan Program IBM SPSS 23. Semarang: Badan Penerbit Universitas Diponegoro.

Hanafi, Mamduh M dan Abdul Halim. 2009. Analisa Laporan Keuangan. Yogyakarta: UPP STIM YKPN.

Houston, Brigham. 2011. Dasar-Dasar Manajemen Keuangan. Edisi 11. Jakarta: Salemba Empat.

Mega Junita,dkk. 2014. Pengaruh Profitabilitas, Pertumbuhan Aset, Operating Leverage dan Ukuran Perusahaan Terhadap Struktur Modal. Jurnal Universitas Riau.

Munawir. 2007. Analisis Laporan Keuangan. Yogyakarta: Liberty.

Nurdin, 2012. Pengaruh Struktur Aktiva Dan Operating Leverage Terhadap Struktur Modal. Jurnal STKIP Pembangunan Indonesia Makassar.

Selvia Nuraini Sarasmita,dkk. 2014. Pengaruh Struktur Aktiva, Profitabilitas, Operating Leverage Dan Tingkat Pertumbuhan Terhadap Modal. Jurnal Universitas Muhammadiyah Semarang.

Suad Husnan dan Enny Pudjiastuti. 2004. Dasar-dasar Manajemen Keuangan. Yogyakarta: UPP AMP YKPN.

Sutrisno. 2013. Manajemen Keuangan Teori Konsep \& Aplikasi. Yogyakarta: EKONISIA.

Riyanto, Bambang. 2012. Dasar-Dasar Pembelanjaan Perusahaan. Edisi 4. Yogyakarta: BPFE Yogyakarta.

Tommy Mardiansyah, 2012. Pengaruh Profitabilitas dan Operating Leverage Terhadap Struktur Modal. Jurnal Universitas Negeri Padang.

Yusuf, Al Haryono. 2003. Dasar Dasar Akuntansi. Yogyakarta: STIE YKPN. 